\title{
Correction to: Male recombination map of the autosomal genome in German Holstein
}

Saber Qanbari ${ }^{*}+\mathbb{D}$ and Dörte Wittenburg ${ }^{* \dagger}$

\section{Correction to: Genet Sel Evol (2020) 52, 73 https://doi.org/10.1186/s12711-020-00593-z}

After publication of the original article [1], the authors reported an error in the contribution declaration. This is to notify that both authors have contributed equally and co-correspond this article.

Published online: 21 January 2021

\section{Reference}

1. Qanbari S, Wittenburg D. Male recombination map of the autosomal genome in German Holstein. Genet Sel Evol. 2020;52:73. https://doi. org/10.1186/s12711-020-00593-z.

\section{Publisher's Note}

Springer Nature remains neutral with regard to jurisdictional claims in published maps and institutional affiliations.

*Correspondence: qanbari@fbn-dummerstorf.de;

wittenburg@fbn-dummerstorf.de

†Saber Qanbari and Dörte Wittenburg contributed equally to this work

Leibniz Institute for Farm Animal Biology (FBN), Institute of Genetics

and Biometry, Wilhelm-Stahl-Allee 2, 18196 Dummerstorf, Germany

(c) The Author(s) 2021. This article is licensed under a Creative Commons Attribution 4.0 International License, which permits use, sharing, adaptation, distribution and reproduction in any medium or format, as long as you give appropriate credit to the original author(s) and the source, provide a link to the Creative Commons licence, and indicate if changes were made. The images or other third party material in this article are included in the article's Creative Commons licence, unless indicated otherwise in a credit line to the material. If material is not included in the article's Creative Commons licence and your intended use is not permitted by statutory regulation or exceeds the permitted use, you will need to obtain permission directly from the copyright holder. To view a copy of this licence, visit http://creativeco mmons.org/licenses/by/4.0/. The Creative Commons Public Domain Dedication waiver (http://creativecommons.org/publicdomain/ zero/1.0/) applies to the data made available in this article, unless otherwise stated in a credit line to the data. 